\title{
THE RIGHTS OF NATIONAL AND ETHNIC MINORITIES AND IMMIGRANTS IN THE CONTEXT OF DYNAMICS OF ETHNIC RELATIONS IN POLAND
}

\author{
Iwona Sobieraj
}

\begin{abstract}
The article presents the situation of national and ethnic minorities and foreigners in Poland in the context of legal and demographic changes that took place between the censuses in 2002 and 2011. There were many factors that affected the situation of minorities in Poland, among them:

- the entry into force of new legislation (primarily the 2006 National and Ethnic Minorities Act),

- activities of the Silesian Autonomy Movement, including the publichearing in the European Court of Human Rights concerning the refusal to register by the Supreme Court in Poland of the Association of Silesian Nationals,

- change of census methodology, among others. By introducing the possibility of a declaration of dual national-ethnic identification,

- increase in immigration in Poland, especially those from the eastern border,

- these factors were presented in statistical and social terms - based on opinion polls in Poland.
\end{abstract}

\section{Keywords}

national and ethnic minorities, foreigners, immigrants, human rights, ethnic relations, sociology

\section{Introduction}

The issue of rights belonging to national and ethnic minorities is complex due to the diversity of national and ethnic forms that occur in many countries, together with Poland. 
The reason for difficulties is also the dynamics of ethnic phenomena, which are subjected to the transformation of the minority groups themselves, of society as a whole and of wider global changes. It is partly imposed on the question of the rights of foreigners / immigrants in the host society. In democratic countries, the rights of national minorities and ethnic groups and immigrants are today a permanent element of the legal order. At the same time, their scope and form and the possibility of enforcement vary from country to country and are subject to change. The solutions in legal aspects usually cause the emotions in the groups which are involved in, as well as the vibrant interest of the media and the public. The largest ones usually when they are grossly out-of-proportion by the majority, or abused by the minority. The purpose of this article is to analyze demographic and social changes within minority relations in Poland in the context of the current legislation between the two recent censuses in 2002 and $2011^{1}$.

\section{The elusiveness of the definition and the dynamics of national and ethnic minorities in Poland}

Among the definitions of minorities we can distinguish, among others: nominal definitions, referring to the number of minorities with respect to the whole of society; normative definitions, emphasizing the legal status of the minority in a given country, and sociological definitions combining objective and subjective criteria for the highlighting of a minority group. The classic sociological definition of the Louis Wirth identifies a minority as a group of people who, because of their physical or cultural characteristics, are distinguished from others living in a given society and therefore treated unequivocally and considered to be discriminated against. The attributes of a minority group in sociological definitions include, but are not limited to: the relatively small number of minority, physical and cultural distinctiveness, intersubjective social ties between members of the minority group and their differentiation from the rest of society, asymmetry of allocation and participation in cultural, social and political life; limited access to power, wealth and prestige, limited political autonomy of the group, group interest integrating members of the group around common values, attributed of membership based on origin and birth, not on election and the historical and symbolic nature of minorities. (Paleczny, 1999, p. 259). With reference to national and ethnic minorities, the issue of their definition in social sciences has been and continues to be a significant difficulty, as is the theoretical and empirical distinction between national and ethnic minorities. More and more definitions are emerging, highlighting the dynamic, declarative, political, and internally differentiated concept of national minorities and ethnic minorities. (Sadowski, 1997, p. 538; Nikitorowicz, 2010)

Issues related to the protection of national minorities became an international concern at the beginning of the twentieth century through the settlement of the League of Nations.

\footnotetext{
1 This article was published in Polish in the book: Global Contexts of Respect for Human Rights and Freedoms, edited by Aleksandra Kuzior, Zabrze 2013.
} 
The issue of the rights of minorities was also discussed during the work on the Universal Declaration of Human Rights, however, there were no provisions explicitly referring to minorities. They are written in Article 27 of the Political Rights Pact: "In the countries where there are ethnic, religious or linguistic minorities, people belonging to these minorities can not be deprived of the right to their own cultural life, profess and practice their own religion and use their own language with other members of the group". Difficulties in agreement on a common definition of the concept of "national minority" resulted in the use of the phrase "people belonging to the minority" without defining the concept itself. The minority rights were defined more precisely by the "Declaration of the Rights of Persons belonging to National or Ethnic, Religious and Linguistic Minorities" adopted by the United Nations General Assembly in 1992. Its signatories undertook to protect the existence and identity of national or ethnic, cultural, religious and linguistic minorities. They granted minority rights the right to develop their culture, practice their religion, use language, and participate in public life. (Kuźnar, 2002, p. 117-118, 422). In 1990 the issue of minority rights was also the subject of CSCE debates within the framework of the Copenhagen conference. It defined the standards that were applicable to the Member States in the area of minority rights, and two years later a permanent position of the High Commissioner for National Minorities was established. The issue of minority rights was also taken up by the Council of Europe, who in 1998 brought about the entry into force of two conventions: the "European Charter for Regional or Minority Languages" and the "European Framework Convention for the Protection of National Minorities".

The necessity of defining the rights and obligations of national and ethnic minorities in Europe was due to many factors that further intensified at the turn of the $20^{\text {th }}$ and $21^{\text {st }}$ centuries. These are:

- Territorial changes and system transformations in Central and Eastern European countries after 1989.

- National and religious conflicts.

- National-origin movements and aspirations of autonomy among various ethnic and cultural groups.

- Increased activity of regional and local communities.

- Demographic changes in the population structure, which were evident, among others, in the censuses.

- Development of international standards for the rights of minorities and their dissemination.

- Empowerment of national minorities in international and internal relations. (Janusz, 2006, p. 11-13).

In Poland, the rights of national and ethnic minorities are defined in the act of 6 January 2005 on National and Ethnic Minorities and on Regional Language. In the act, the national minority was defined as a group of Polish citizens, which fulfills the following conditions:

- is less populous than the rest of the population of the Republic of Poland;

- significantly differentiates itself from other citizens by language, culture or tradition;

- aims to preserve its language, culture or tradition; 
- is aware of its own historical national community and is geared towards its expression and protection;

- its ancestors have lived in the present territory of the Republic of Poland for at least 100 years;

- identifies with a nation organized in its own state. (Dz. U. 2005 nr 17 poz. 141, 2005) On the other hand, the definition of an ethnic minority was created by repeating the first five points of the definition of a national minority by referring to the ethnic community and denouncing the last one: "it does not identify with a nation organized in its own state." (Dz. U. 2005 nr 17 poz. 141, 2005). The national minorities recognized in Poland: the Belarusian, Lithuanian, German, Armenian, Russian, Slovak, Ukrainian and Jewish, and ethnic minorities: Karaite, Lemko, Romani, and Tatar.

The act was the result of work of a committee of representatives from many ethnic groups, and the work on it was difficult and led to a compromise that was not satisfactory to all parties. During the drafting of the bill, the issues of minority definition and bilingual regulations were the most controversial. (Łodziński, 2006, p. 292-293). On the fifth anniversary of the signing of the act, its creators were talking about the work in Gazeta Wyborcza: "The act, passed in 2005, is the longest accepted of all passed by the Polish parliament. Since 1994, the team has been working on it, with the addition of prof. Rzeplinski who was the president of the Helsinki Foundation for Human Rights, Marek Nowicki, the head of the Department of Penitentiary Law at the Jagiellonian University and the member of the Helsinki Foundation for Human Rights Zbigniew Hołda and prof. Grzegorz Janusz. It was created after Jacek Kuroń, the chairman of the parliamentary committee for national minorities, came to the foundation to prepare a preliminary draft. (...) Prof. Rzeplinski: - In fact, thinking like that was clear among the politicians: since in Lithuania the Polish minority has no privileges, why should Lithuanian minority should have any in Poland? We tried to explain that according to international law human rights do not apply to the principle of reciprocity based on the premise - "if they do us wrong, we do them too". On the contrary. Since we are aware that Polish minority is discriminated somewhere, let us show them how the model of cooperation between the minority and the state should look like. This can prompt our neighbors to changes. Probably the biggest enemy of the bill was the short-sightedness of some politicians, the inclination of some deputies and officials to xenophobia, lack of knowledge of the broader context." (Reszka, 2010).

The National Census of Population and Housing of 2002 was published during the work on the act. It contained a question about the nationality of the respondent, in response to which 471,475 people declared nationality other than Polish, and 774,885 people did not give their nationality. The largest group that declared its nationality as non-Polish were the Silesians - 172,682 people. On the second place were people declaring German nationality - 147,094 people. The next were Belarusian, Ukrainian, Romanian, Russian, Lemkos, Lithuanian, Kashubian, Slovakian, Vietnamese, French, American, Greek, Italian, Jewish, Bulgarian and Armenian nationalities which were declared by more than 1,000 people each and others which were declared by less than 1,000 people, and a total of 109 different ethnic groups and nationalities. (Główny Urząd Statystyczny, n.d.). The 
results of the 2002 census were met with the accusations of minority organizations and associations, including the Silesian Autonomy Movement, the Association of Ukrainians in Poland, and the German Minority Association because of many examples of refusal of entry of non-Polish nationals or writing them with a pencil. The weakness of the Census, which was referred to by minority organizations, was also the lack of possibility to declare dual nationality.

This situation was changed in the National Population and Housing Census in 2011. In the Census, 871,000 people used the possibility of choosing dual nationality, a total of 1,388 thousand people declared non-Polish nationality (including double Polish-foreign). The analysis of the census results done by the statistics indicates that the dynamics of ethnic relations in Poland was noticed. "The latest census data show an increase in the sense of ethnic separateness of regional communities in Poland, although in most cases this is connected with the simultaneous feeling of Polish national identity. Among the most numerous non-Polish national-ethnic identities belong Silesian and Kashubian declarations. In total, as a response to the first or second ethnic question - 809,000 Silesian declarations, with less than half of them $(362,000)$ expressed as a single identification, and more often identified as Silesian together with Polish one -415,000. Among 228,000 of the total number of people declaring Kashubian affiliation, 212 thousand were the ones that declared Polish-Kashubian affiliation, while 16,000 - exclusively Kashubian." (Results of the National Census of Population and Housing, 2012, p. 17).

Particularly in relation to the Silesian and Kashubian population, there are changes that significantly affect the dynamics of ethnic relations in Poland. The media was showing the trial of the registration of the Association of Silesian Nationality, which ended in the Supreme Court in 1998 with the refusal to register. The response to this court decision was a complaint filed with the European Court of Human Rights and rejected in 2004. These events for long animated discussions on the issues of the nation, minority groups, and permeated the media through public awareness, feedback, and stimulated reflection (often critical) on the state of the rights of national and ethnic minorities in Poland as well as the extent of loyalty of national and ethnic minorities to the country in which they reside.

According to Professor Ewa Nowicka, a longtime researcher of ethnic issues in Poland and Europe: "It is unprofessional to say that ethnic ties lose their meaning in today's world. The changes that are willingly and certainly due to conceptual helplessness, termed civilizational, lead to profound changes in the phenomenon of ethnic ties. Politicization and instrumentalisation of ethnicity are indicated. Having a culture of its own, unique, specific, untypical and quaint is the foundation for the existence of an ethnic / national group. At the same time, relying on such a culture is increasingly becoming a condition of gaining the status of an ethnic group or nation, a status that gives both tangible political and legal advantages and less tangible benefits. The group's status as a nation or ethnic group gives it certain privileges; it becomes a political subject to a specific set of recognized rights, acting at both local and regional and international levels of relations and institutions." (Nowicka, 2007, p. 489-480).

The question now remains whether and how current statistics and minority actions will 
shape changes in policy and legislation towards minorities. The examples of Silesians and Kashubians show that processes that were once perceived as longtime, in the information society and thanks to political elites of these groups can influence national self-declarations and accelerate changes in the awareness of members and potential members of these groups. According to Ernest Renan, "nationality is a daily plebiscite" - members of different ethnic and national groups living in Poland are more and more willing to take part in it and declare their identification. In less than 10 years between the censuses (2002-2011) there was more than $200 \%$ increase of the number of people declaring non-Polish nationality in Poland, and although it has a small scale (from $1.23 \%$ to $3.60 \%)$, it is difficult not to notice the difference. We do not know to what extent this change results from the change in the census methodology, and to what extent to relation to wider social processes.

\section{Immigrants in Poland - legal and social situation}

Foreigners, both in Polish legislation and in census statistics, are defined as people residing in Poland who do not have Polish citizenship. On the other hand, the concept of immigrant is less acute. Immigration is, according to the sociological definition, "a voluntary or forced movement of foreigners settling permanently in a country, and immigrants are a group of people settled permanently in a country." (Olechnicki \& Załęcki, 1997). It is assumed that immigration is relatively durable, although this criterion is blurred. For census purposes it is assumed that permanent residence is a stay of at least 12 months. However, the literature distinguishes between fixed and temporary migrations, most of which include job migration. Among other types of migration that significantly determine the situation of immigrants, voluntary and involuntary migration (e.g. resettlement, deportation, expulsion) and legal and illegal migration (which determine the status of immigrant in the target country) should be distinguished. (Kubiak \& Slany, 1999, p. 243-249).

Observing the demographic and statistical data on migration in Poland, it is noted that despite the still small scale of this phenomenon, the demographic situation here is also dynamic. According to census data from 2011, only $0.1 \%$ (57.5 thousand) of Polish residents were foreigners. The results of the census show that over 327 thousand of Polish people also had other nationalities (German: 239.3 thousand), American (29.6 thousand), Canadian (8.9 thousand), French (6.3 thousand), Italian (6.1 thousand) and British (4.7 thousand) and almost 1.6 thousand people had two non-Polish nationalities. The number of people with non-Polish citizenship in 2011 was higher than in 2002. The total number of foreigners temporarily residing in Poland from 3 to 12 months was included in the list of 56,300 , but it is believed to be underestimated because of the representative census methodology, and the widespread perception among immigrants that the census only applies to Polish citizens. (Narodowy Spis Powszechny Ludności i Mieszkań 2011, 2012). Another source of information on foreigners residing in Poland is the data of the Office for Foreigners concerning applications submitted and types of residence permits issued. 
In 2012 the number of applicants for refugee status reached the highest recorded value of 10,753 . There are also statistics on visas and invitations issued to foreigners. Over 70,000 invitations and over 3,000 visas were issued in 2012. (UDSC, n.d.). Information on the temporary employment of foreigners in Poland is also provided by the Ministry of Labor and Social Policy in the form of statistics on work permits issued. According to the latest report in 2012 in Poland over 39 thousand work permits were issued. In 2011 there were slightly over 40 thousand permits, and in 2010 more than 36.5 thousand. (Report of the Ministry of Labor and Social Policy, Foreigners working in Poland, n.d.). These statistics, however, do not include foreigners from the east (among others: Ukrainians, Belarussians, Russians, Moldovan and Georgians) who can work in Poland for 6 months on the basis of a statement submitted to the county employment office as well as difficult to estimate number of foreign workers who are working illegally.

The basic act which regulates the rules of staying of the foreigners in Poland is the Act of 13 June 2003 on Foreigners. A foreigner is anyone who does not have Polish citizenship, except: representatives of diplomatic staff, representatives of EU countries, EFTA parties to the agreement on the European Economic Area or the Swiss Confederation, asylum seekers and political asylum seekers and repatriates. (Dz. U. 2011 nr 264 poz. 1573, 2011). The legal situation of foreigners residing in Poland depends on their legal status, and because of this criterion they can be divided into the following categories:

- people with a temporary residence permit (temporary residence),

- people with residence permit,

- people with a work permit,

- people with a refugee status and subsidiary protection status,

- people with tolerated stay permit. (Wybrane pojęcia i terminy - Migracja cudzoziemców do Polski, 2010).

Important legal and economic conditions that affect the situation of foreigners in Poland may also include changes in the law concerning employment of foreigners. Facilitation of employment of foreigners is introduced, but they primarily concern citizens of the European Union and some Eastern European countries, while formalities and economic requirements have been introduced for countries that have a visa requirement after Poland's accession to the European Union. In addition, these conditions are complicated by the economic crisis and the difficult situation on the Polish labor market.

The attitude of Poles to foreigners is generally characterized by several factors:

- low proportion of foreigners in the population,

- low level of contact between Poles and foreigners,

- increased acceptance for foreigners working in Poland,

- a greater willingness to be open to foreigners when the people experienced personal contact (e.g. with a foreigner living in Poland or as a result of their own migration experience),

- conditional and limited acceptance of foreigners. (Wenzel, 2009).

The feeling of sympathy or antipathy of Poles towards foreigners depends also on the extent to which they are similar to Poles in a racial, ethnic and cultural way (the more similar they are, the better they are perceived) and the second factor is the level of 
perceived wealthy (the richer, the better). In some situations, the role of economic factors seems to be less significant, e.g. to those from the former USSR, who are often met with reluctance. (Wenzel, 2009).

In a survey conducted by CBOS in 2010, every fourth Pole declared that they know personally a foreigner living in Poland. Most commonly declared were representatives of such nationalities as Ukrainians, Russians, Belarussians, Germans, and Brits. This fact in further research proved to be important, because it significantly influenced a more positive attitude towards foreigners. The vast majority of the respondents (81\%) accepted the possibility of taking up work in Poland by foreigners, but one third of the respondents limited their acceptance to certain types of work, most of which were the ones they did not want or could not do because of low wages or lack of adequate specialists. Poles also made their consent to the work of foreigners in Poland if there were no Poles willing to undertake a given job. In a situation of crisis, the Poles felt a threat to their attitude towards foreigners working in the East, as $65 \%$ of respondents believed that the government should strive to reduce the number of workers from the East. (Feliksiak, 2010).

\section{Conclusions}

In Western Europe, ethnic processes are very dynamic and occur on a much larger scale than in Poland. The problems faced by many Western European countries have prompted in-depth reflection on the rights and obligations of minorities and immigrants, as these problems and their specific solutions may provide a basis for future action in Poland as well. (Sobieraj, 2011, p. 97-106). The ethnic and national processes occurring in Poland and concerning minorities and immigrant groups, as well as the shaping of legislation regulating this sphere of public life, are part of the construction of democratic governance. This is a process that is more and more public in the course of which there is a public discourse between the minorities and the majority and the scope of the minority's discretion and the will to respect it. (Sadowski, 1997, p. 533). In this process, there are specific difficulties that arise from factors such as:

- diversity of national and ethnic groups in Poland (in terms of their pedigree, geographical distribution, number, national or ethnic character),

- internal diversity and the lack of heterogeneity of minorities (e.g. among Lemkos, Silesians, Germans, Roma),

- overlapping and crossing ethnic and national minorities with an autochthonous character, with immigrant groups,

- a diverse situation in region and local communities, where the minority may actually be a dominant group (e.g. because of numerical superiority, economic or a significant role in local government),

- demographic and statistical changes in minority numbers (e.g. as a result of assimilation of subsequent generations or revitalization of ethnic identity, but also as a result of spatial migration). 
These factors put lawmaking in the protection of minorities at the beginning in the face of many restrictions and it is condemned to numerous imperfections. Inclusion in the legislative processes demographic, social and cultural changes, as well as the diversity of the minority as a social category is not an easy task, and in many situations simply impossible or pointless. This gap should be filled with education for multiculturalism, covering not only human rights issues but also other cultural backgrounds, but also showing the importance of multiculturalism in Poland and in the contemporary world and raising awareness of the need for intercultural competences. In the age of globalization, the implementation of international legal standards is often insufficient to maintain good ethnic relations in many countries. Recognition of minority rights can not be a one-off fact, and both rights and obligations should be constantly negotiated in open social dialogue.

\section{References}

Dz. U. 2005 nr 17 poz. 141. (2005). Retrieved March 22, 2013, from http://isap.sejm.gov. pl/DetailsServlet?id=WDU20050170141

Dz. U. 2011 nr 264 poz. 1573. (2011). Retrieved February 23, 2013, from http://isap.sejm. gov.pl/DetailsServlet?id=WDU20112641573

Feliksiak, M. (2010). Praca cudzoziemców w Polsce. Raport CBOS, BS/148/2010. Warszawa: Fundacja Centrum Badania Opinii Społecznej. Retrieved February 23, 2013, from https://www.cbos.pl/SPISKOM.POL/2010/K_148_10.PDF

Główny Urząd Statystyczny. (n.d.). Retrieved February 23, 2013, from http://www.stat. gov.pl/gus/8185_PLK_HTML.htm

Janusz, G. (2006). Statystyczny obraz mniejszości narodowych we współczesnej Europie. In E. Michalik, \& H. Chałupczak, Mniejszości narodowe i etniczne w procesach transformacji oraz integracji. Lublin: Wydawnictwo UMCS.

Kubiak, H., \& Slany, K. (1999). Migracje. In W. Kwaśniewicz, Encyklopedia Socjologii, t. 2. Warszawa: Oficyna Naukowa.

Kuźnar, R. (2002). Prawa człowieka. Prawo, instytucje, stosunki międzynarodowe. Warszawa: Wydawnictwo Naukowe Scholar.

Łodziński, S. (2006). Spory wokół ustawy o ochronie mniejszości narodowych i etnicznych w Polsce. In E. Michalik, \& H. Chałupczak, Mniejszości narodowe i etniczne w procesach transformacji oraz integracji. Lublin: Wydawnictwo UMCS. 
Narodowy Spis Powszechny Ludności i Mieszkań 2011. Raport z wyników. (2012). Warszawa: Zakład Wydawnictw Statystycznych. Retrieved February 23, 2013, from http:// www.stat.gov.pl/cps/rde/xbcr/gus/lud_raport_z_wynikow_NSP2011.pdf

Nikitorowicz, J. (2010). Grupy etniczne w wielokulturowym świecie. Sopot: Gdańskie Wydawnictwo Psychologiczne.

Nowicka, E. (2007). Odmienność kulturowa jako wartość? Wymiar etniczny społeczeństwa polskiego. In A. Kojder, Jedna Polska? Dawne i nowe zróżnicowania społeczne (pp. 489480). Kraków: Wydawnictwo WAM, PAN.

Olechnicki, K., \& Załęcki, P. (1997). Słownik Socjologiczny. Toruń: Graffiti BC.

Paleczny, T. (1999). Mniejszości. In W. Kwaśniewicz, Encyklopedia Socjologii, t. 2 K-N. Warszawa: Oficyna Naukowa.

Report of the Ministry of Labor and Social Policy, Foreigners working in Poland. Statistics. (n.d.). Retrieved February 23, 2013, from http://www.mpips.gov.pl/analizy-i-raporty/ cudzoziemcy-pracujacy-w-polsce-statystyki

Results of the National Census of Population and Housing. Basic information on the demographic and social situation of the Polish population and housing resources. (2012). Retrieved February 23, 2013, from http://www.stat.gov.pl/cps/rde/xbcr/gus/lu_nps2011_ wyniki_nsp2011_22032012.pdf

Reszka, P. (2010). By nie byli obcy. Jak powstała ustawa?. Retrieved February 23, 2013, from http://lublin.gazeta.pl//ublin/1,35638,8378500,By_nie_byli_obcy_Jak_ powstawala_ustawa.html\#ixzz2Mn5oNNxm

Sadowski, A. (1997). Narodowościowe i etniczne zróżnicowanie III RP. In A. Kojder, Jedna Polska? Dawne i nowe zróżnicowania społeczne. Kraków: Wydawnictwo WAM, PAN.

Sobieraj, I. (2011). Wolność i powinność. Prawa człowieka i prawa mniejszości w społeczeństwach pluralistycznych. In A. Kuzior, Globalne konteksty poszanowania praw i wolności człowieka. Prawa człowieka w społecznej praktyce (pp. 97-106). Sosnowiec: Katedra Stosowanych Nauk Społecznych Politechniki Śląskiej.

UDSC (Urząd do Spraw Cudzoziemców). (n.d.). Zestawienia Roczne. Retrieved February 23, 2013, from http://www.udsc.gov.pl/Zestawienia,roczne,233.html

Wenzel, M. (2009). Stosunek Polaków do obcokrajowców w Polsce. Warszawa: Instytut Spraw Publicznych. Retrieved February 23, 2013, from http://www.isp.org.pl/fil es/7735258070251767001254129661.pdf 
Wybrane pojęcia i terminy - Migracja cudzoziemców do Polski. (2010). Retrieved March 23，2013， from http://www.agenda21. waw.pl/index.php?option=com content\&view $=$ article\&id $=31 . . \&$ limitstart $=2$

\section{Author}

dr Iwona Sobieraj

Institute of Sociology, University of Opole

ul. Katowicka 89, 45-061 Opole, Poland

isobieraj@uni.opole.pl 